\title{
Behavioural treatments for chronic systemic inflammation: effects of dietary weight loss and exercise training
}

\author{
Barbara J. Nicklas, Tongjian You, Marco Pahor
}

Abstract

PeRsistent LOW-GRADE INFLAMmation, as indicated by higher circulating levels of inflammatory mediators such as C-reactive protein, interleukin- 6 and tumour necrosis factor- $\alpha$, is a strong risk factor for several chronic diseases. There are data indicating that decreasing energy intake and increasing physical activity may be effective therapies for reducing overall inflammation. Evidence is strong that circulating levels of inflammatory markers are elevated with total and abdominal obesity, possibly owing to a higher secretion rate of cytokines by adipose tissue in obese people. Moreover, verylow-energy dietary weight loss reduces both circulating markers of inflammation and adipose-tissue cytokine production. Data from several large population-based cohorts show an inverse association between markers of systemic inflammation and physical activity or fitness status; small-scale intervention studies support that exercise training diminishes inflammation. Dietary weight loss plus exercise is likely more effective than weight reduction alone in reducing inflammation. To date, data from randomized, controlled trails designed to definitively test the effects of weight loss or exercise training, or both, on inflammation are limited. Future studies are required to define the amount of weight loss needed for clinically meaningful reductions of inflammation; in addition, fully powered and controlled studies are necessary to clarify the effect of exercise training on chronic, systemic inflammation.

CMAJ 2005;172(9):1199-209

$\mathrm{T}$ he biologic cascade of events that form the body's natural defenses against injury or infection is a vital part of the immune system. Ordinarily, this process is an acute response resulting in rapid, major increases in inflammatory mediators released into the circulation. ${ }^{1,2}$ In healthy, lean, non-elderly people, for example, blood concentrations of the acute-phase reactant C-reactive protein (CRP), which are normally less than $2 \mathrm{mg} / \mathrm{L}$ in $\mathrm{men}^{3}$ and less than $2.5 \mathrm{mg} / \mathrm{L}$ in women, ${ }^{4}$ can increase more than 1000 -fold in response to infection or trauma. ${ }^{2,5,6}$

Typically, a CRP value of $10 \mathrm{mg} / \mathrm{L}$ or more is considered indicative of clinically significant inflammation. ${ }^{7}$ However, recent evidence indicates that persistent elevations in circulating markers of inflammation, even when within the clinically normal range, are risk factors for cardiovascular disease in both middle-aged ${ }^{8-13}$ and older ${ }^{14-19}$ people. Recently, the US Centers for Disease Control and Prevention and the American Heart Association have stated that people with CRP val- ues in the upper tertile of the adult population $(>3.0 \mathrm{mg} / \mathrm{L})$ have a risk of cardiovascular disease that is double that of people whose CRP concentrations are less than $1.0 \mathrm{mg} / \mathrm{L} .^{20}$ In addition to CRP, interleukin-6 (IL-6) and tumour necrosis factor-alpha (TNF- $\alpha$ ), along with several other acutephase reactant proteins, cytokines and cytokine-soluble receptors, are strongly associated with increased risk for several chronic diseases, including cardiovascular disease, ${ }^{12,17,21,22}$ diabetes mellitu ${ }^{23,24}$ and disability. ${ }^{25,26} \mathrm{IL}-6$ and TNF- $\alpha$ are both stimulators of CRP release from hepatocytes. ${ }^{27,28}$ It is not yet known which of these factors might be the most robust indicator of underlying inflammation, or whether the effects of these biomarkers are additive for risk prediction.

As illustrated in Figure 1, behavioural factors are associated with chronic, low-grade states of inflammation (as measured by slightly elevated inflammatory biomarkers), and therefore with the several chronic diseases that are associated with inflammatory states. Since the risk estimates associated with elevated inflammation appear to be linear (e.g., the CRP category cut-offs for assessment of cardiovascular disease risk ${ }^{20}$ are low risk $<1.0 \mathrm{mg} / \mathrm{L}$, medium risk $1.0-3.0$ $\mathrm{mg} / \mathrm{L}$ and high risk $>3.0 \mathrm{mg} / \mathrm{L}$ ), behavioural interventions that produce even slight reductions in inflammation may have clinically significant benefits. A few pharmacologic interventions such as use of angiotensin-converting-enzyme inhibitors and statins decrease inflammation, as evidenced by lowered CRP concentrations in prospective clinical trials..$^{29-32}$ Moreover, there are very promising data suggesting that decreasing body weight and increasing physical activity are just as effective as medication for reducing overall inflammation. The published effects of behavioural interventions involving weight loss and exercise training on inflammatory markers are reviewed here.

\section{Role of adiposity and weight loss in regulating inflammation}

\section{Evidence from observational studies}

The association between excess adipose tissue (measured either indirectly by body mass index [BMI] or directly by body composition assessment) and elevated CRP concentrations ${ }^{33-51}$ has been observed to hold for children, ${ }^{36,40,45}$ elderly 
people ${ }^{14,50}$ and people with metabolic syndrome, ${ }^{49}$ diabetes $^{48}$ and heart disease..$^{52}$ In fact, obesity may account for a large portion of variation in circulating CRP concentrations; in a population-based study involving healthy, middle-aged women, ${ }^{35}$ for example, BMI explained $30 \%$ of the variance in CRP concentrations. In an analysis ${ }^{33}$ of the Third National Health and Nutrition Examination Survey, the proportion of people with a CRP level above $10 \mathrm{mg} / \mathrm{L}$ (the traditional clinical level suggestive of infection) was $20 \%$ in obese women, but only $4 \%$ in women whose weight was within the normal range. Obese participants were more likely than participants of normal weight to have an elevated CRP level, by an odds ratio of 2.13 for men (95\% confidence interval [CT 1.562.91) and 6.21 for women (95\% CI 4.94-7.81). ${ }^{33}$ Similarly, in

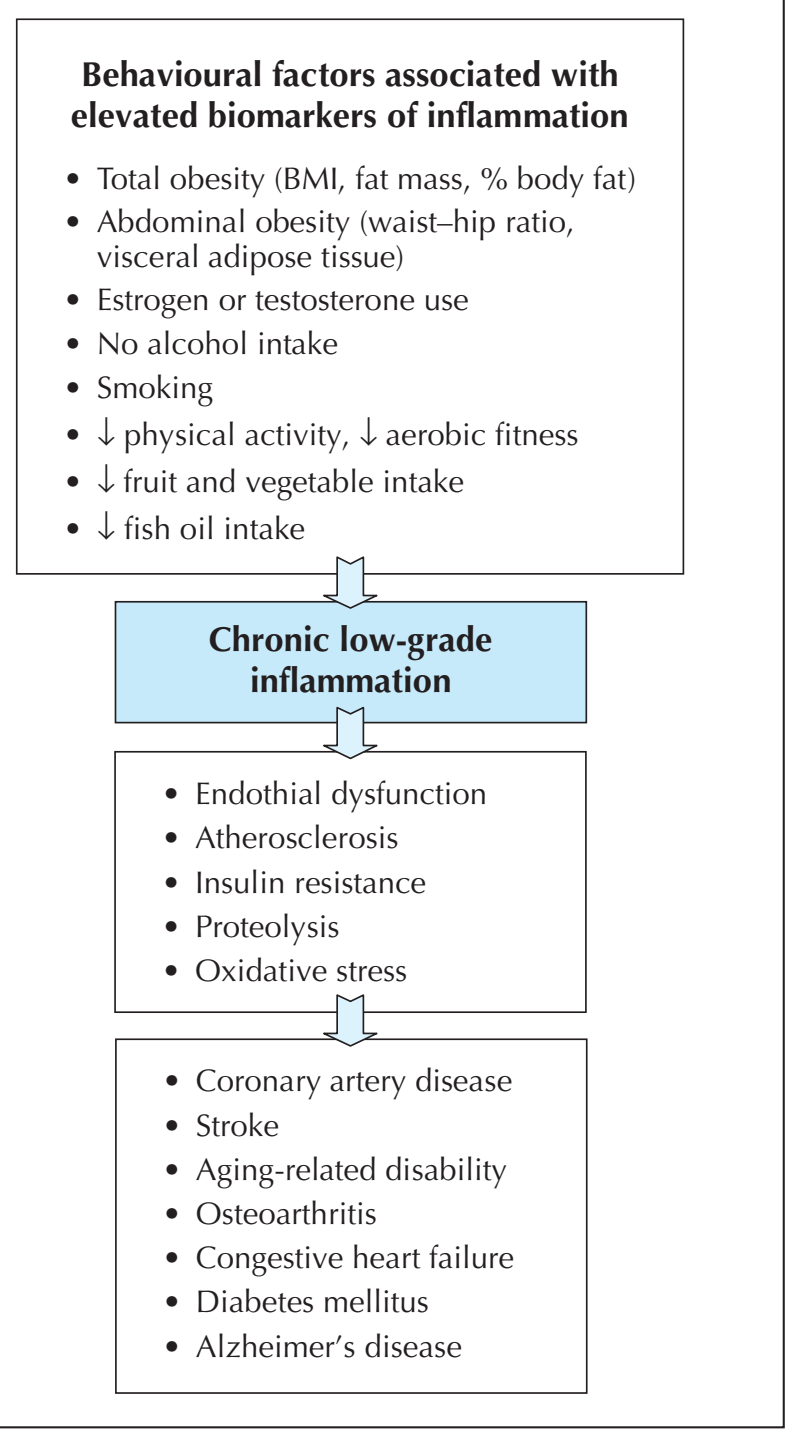

Fig. 1: Reported behavioural factors associated with chronic subclinical inflammation, and diseases and adverse health conditions for which inflammation is a risk factor. $\downarrow=$ decreased; $\mathrm{BMI}=$ body mass index. a study involving 1929 middle-aged men and women, ${ }^{49} 15 \%$ of obese participants had a CRP level above $10 \mathrm{mg} / \mathrm{L}$, compared with only $3 \%$ of normal-weight people.

Other inflammatory markers, including the cytokines IL$6,{ }^{34,53-60}$ TNF- $\alpha,{ }^{34,58,59,61-65}$ TNF- $\alpha$ receptors, ${ }^{57,60,63,66-68} \mathrm{IL}-8,{ }^{69,70}$ $\mathrm{IL}-18^{56,58,59,71}$ and $\mathrm{IL}-1$ receptor antagonist, ${ }^{72,73}$ are elevated in obese people. Haptoglobin and serum amyloid protein A, both proteins involved in the acute-phase response to inflammation, have also been shown to circulate in higher concentrations in people with more body fat. ${ }^{74-76}$ The sample sizes in these studies are smaller and typically not population-based, but across these studies the data are consistent. In an interesting study $y^{63}$ involving identical twins discordant for obesity (the average difference in body weight between twin pairs was $18 \mathrm{~kg}$ ), levels of TNF- $\alpha$ and soluble TNF- $\alpha$ receptor 2 (sTNFR2) were higher in obese than in lean twins, which suggests that obesity rather than other genetic factors is a major determinant of these inflammatory markers.

Lastly, there is some evidence from observational studies involving both men and women that, in addition to total body fat, visceral (abdominal) body fat may be an independent predictor of inflammatory markers. ${ }^{37,38,43,44,64,77,78}$ In 2 studies $^{77,78}$ the amount of visceral fat was a better determinant of CRP levels than other measures of obesity, including fat mass. The location of body fat, independent of total amount, is therefore an important factor affecting chronic inflammation.

Adipose tissue is known to be a secretory organ producing cytokines, acute-phase reactants and other circulating factors. ${ }^{79-81}$ The source of these "adipokines" is likely not the adipocyte itself, but the infiltration of inflammatory cells (macrophages) into adipose tissue. ${ }^{82,83}$ In vivo release of IL-6 and TNF-soluble receptors from subcutaneous abdominal adipose tissue has been shown to correlate with BMI and body-fat proportion. ${ }^{84}$ Moreover, TNF- $\alpha$ gene and protein expression in both subcutaneous and visceral adipose tissue are greater in obese than in lean people. ${ }^{85,86} \mathrm{In}$ one in-vitro study $^{87}$ TNF- $\alpha$ release from abdominal subcutaneous adipose tissue was 7.5-fold higher in tissue from obese (BMI $\left.30-40 \mathrm{~kg} / \mathrm{m}^{2}\right)$ than lean $\left(\mathrm{BMI}>25 \mathrm{~kg} / \mathrm{m}^{2}\right)$ subjects. ${ }^{87}$ Ouchi and associates ${ }^{81}$ reported not only that CRP is expressed in adipose tissue, but also that $\mathrm{CRP}$ and adiponectin mRNA levels are highly inversely related. (Adiponectin is a protein with anti-inflammatory properties.)

Thus, both in vivo and in vitro studies confirm that adipose tissue expression and release of cytokines are elevated in people with a higher adipose mass.

\section{Evidence from intervention studies}

The hypothesis that an expanded adipose-tissue mass contributes to an elevated state of chronic inflammation is corroborated by data (summarized in Table 1) showing that weight loss reduces inflammation. Several markers of inflammation, including CRP, IL-6, IL-18, TNF- $\alpha$ and TNF- $\alpha$ receptors, are reduced after weight loss achieved through short-term intense dietary restriction, ${ }^{53,88-91}$ 
Table 1: Summary of published data on the effects of weight loss on systemic markers of inflammation

\begin{tabular}{|c|c|c|c|c|c|}
\hline $\begin{array}{l}\text { Author group and } \\
\text { year of publication }\end{array}$ & $\begin{array}{l}\text { Participants and } \\
\text { mean BMI, kg/m² }\end{array}$ & $\begin{array}{l}\text { Intervention } \\
\text { for weight loss }\end{array}$ & Duration & $\begin{array}{l}\text { Magnitude of } \\
\text { weight loss }\end{array}$ & $\begin{array}{c}\text { Effects on } \\
\text { inflammatory markers }\end{array}$ \\
\hline \multicolumn{6}{|l|}{$\begin{array}{l}\text { Intense, short-term } \\
\text { dietary restriction }\end{array}$} \\
\hline Xydakis et al ${ }^{91} 2004$ & $\begin{array}{l}40 \text { obese adults with } \\
\text { metabolic syndrome } \\
\text { BMI } 38.9 \pm 1.0\end{array}$ & $\begin{array}{l}600-800 \mathrm{kcal} / \mathrm{d} \\
\text { very-low-calorie diet }\end{array}$ & $4-6 w k$ & $7.0 \%$ of weight & $\begin{array}{l}\text { CRP } \downarrow 14 \% \text {; } \\
\text { no change in TNF- } \alpha\end{array}$ \\
\hline Heilbronn et al ${ }^{89} 2001$ & $\begin{array}{l}83 \text { obese women } \\
\text { BMl } 33.8 \pm 0.4\end{array}$ & $\begin{array}{l}\text { Low-fat }(15 \%), 1360 \mathrm{kcal} / \mathrm{d} \\
\text { energy-restricted diet }\end{array}$ & $12 \mathrm{wk}$ & $7.9 \mathrm{~kg}$ & $\mathrm{CRP} \downarrow 26 \%$ \\
\hline Gallistl et $\mathrm{al}^{90} 2001$ & $\begin{array}{l}49 \text { obese children } \\
\text { BMI } 26.7 \pm 1.4\end{array}$ & $\begin{array}{l}\text { 908-1194 kcal/d } \\
\text { energy-restricted diet }\end{array}$ & $3 \mathrm{wk}$ & $\begin{array}{l}5.2 \% \text { of } \mathrm{BMl}, \\
3.1 \% \text { of fat mass }\end{array}$ & IL- $6 \downarrow 49 \%$ \\
\hline Bastard et $a^{53} 2000$ & $\begin{array}{l}14 \text { obese women } \\
\text { BMI } 39.5 \pm 1.1\end{array}$ & $\begin{array}{l}941 \mathrm{kcal} / \mathrm{d} \\
\text { very-low-calorie diet }\end{array}$ & $3 \mathrm{wk}$ & $\begin{array}{l}5.3 \% \text { of } \mathrm{BMI}, \\
8.5 \% \text { of fat mass }\end{array}$ & $\begin{array}{l}\text { IL- } 6 \downarrow 17 \% \text {; } \\
\text { no change in CRP, TNF- } \alpha\end{array}$ \\
\hline Bastard et al ${ }^{88} 2000$ & $\begin{array}{l}17 \text { obese women } \\
\text { BMI } 39.9 \pm 1.6\end{array}$ & $\begin{array}{l}941 \mathrm{kcal} / \mathrm{d} \\
\text { very-low-calorie diet }\end{array}$ & $3 \mathrm{wk}$ & $5.0 \%$ of fat mass & $\begin{array}{l}\text { sTNFR1 } \downarrow 8 \% ; \\
\text { no change in sTNFR2 }\end{array}$ \\
\hline \multicolumn{6}{|l|}{$\begin{array}{l}\text { Longer-term } \\
\text { behavioural changes }\end{array}$} \\
\hline Marfella et a $\left.\right|^{58} 2004$ & $\begin{array}{l}67 \text { obese pre- } \\
\text { menopausal women } \\
\text { BMI } 36.5 \pm 1.8\end{array}$ & $\begin{array}{l}1300 \mathrm{kcal} / \mathrm{d} \\
\text { energy-restricted diet, } \\
\text { increased exercise }\end{array}$ & $12 \mathrm{mo}$ & $13.4 \%$ of weight & $\begin{array}{l}\text { CRP } \downarrow 44 \% ; \text { IL- } 6 \downarrow 62 \% ; \\
\text { TNF- } \alpha \downarrow 31 \% ; \text { IL-18 } \downarrow 30 \%\end{array}$ \\
\hline \multirow[t]{2}{*}{ Seshadri et al ${ }^{94} 2004$} & \multirow{2}{*}{$\begin{array}{l}78 \text { obese adults, } \\
86 \% \text { with diabetes or } \\
\text { metabolic syndrome } \\
\text { BMI } 43.5 \pm 1.3\end{array}$} & $\begin{array}{l}\leq 30 \mathrm{~g} / \mathrm{d} \text { low-carbohydrate } \\
\text { diet, or }\end{array}$ & $6 \mathrm{mo}$ & $8.5 \mathrm{~kg}$ & $\mathrm{CRP} \downarrow 12 \%$ \\
\hline & & $\begin{array}{l}500 \mathrm{kcal} / \mathrm{d} \text { deficit energy- } \\
\text { restricted diet }\end{array}$ & $6 \mathrm{mo}$ & $3.5 \mathrm{~kg}$ & $\mathrm{CRP} \downarrow 7 \%$ \\
\hline Monzillo et al ${ }^{93} 2003$ & $\begin{array}{l}24 \text { obese healthy } \\
\text { and diabetic adults } \\
\text { BMI } 36.7 \pm 0.9\end{array}$ & $\begin{array}{l}500 \mathrm{kcal} / \mathrm{d} \text { deficit } \\
\text { energy-restricted diet and } \\
\text { moderate-intensity exercise }\end{array}$ & $26 w k$ & $7.0 \%$ of weight & $\begin{array}{l}\text { IL- } 6 \downarrow 41 \% \text {; } \\
\text { no change in TNF- } \alpha\end{array}$ \\
\hline Bruun et al ${ }^{70} 2003$ & $\begin{array}{l}19 \text { obese men } \\
\text { BMI } 38.7 \pm 0.7\end{array}$ & $\begin{array}{l}1000-1480 \mathrm{kcal} / \mathrm{d} \\
\text { energy-restricted diet }\end{array}$ & $16 \mathrm{wk}$ & $14.7 \%$ of weight & $\begin{array}{l}\text { IL-6 } \downarrow \downarrow 24 \% ; \text { TNF- } \alpha \downarrow 29 \% ; \\
\text { IL-8 } \downarrow 30 \%\end{array}$ \\
\hline Tchernof et al $^{42} 2002$ & $\begin{array}{l}25 \text { obese post- } \\
\text { menopausal women } \\
\text { BMI } 35.2 \pm 1.0\end{array}$ & $\begin{array}{l}1200 \mathrm{kcal} / \mathrm{d} \\
\text { American Heart Association } \\
\text { Step II diet }\end{array}$ & $14 \mathrm{mo}$ & $\begin{array}{l}15.6 \% \text { of weight, } \\
25 \% \text { of fat mass, } \\
36.4 \% \text { of visceral fat }\end{array}$ & $\mathrm{CRP} \downarrow 32 \%$ \\
\hline Ziccardi et al ${ }^{43} 2002$ & $\begin{array}{l}56 \text { obese women } \\
\text { BMI } 37.2 \pm 2.2\end{array}$ & $\begin{array}{l}1300 \mathrm{kcal} / \mathrm{d} \text { energy- } \\
\text { restricted diet, increased } \\
\text { exercise }\end{array}$ & $12 \mathrm{mo}$ & $12.6 \%$ of $\mathrm{BMI}$ & IL-6 $\downarrow 47 \% ;$ TNF- $\alpha \downarrow 31 \%$ \\
\hline Esposito et al ${ }^{92} 2002$ & $\begin{array}{l}40 \text { obese women } \\
\text { BMI } 36.4 \pm 2.0\end{array}$ & $\begin{array}{l}1300 \mathrm{kcal} / \mathrm{d} \text { energy- } \\
\text { restricted diet, behavioural } \\
\text { and nutritional counselling }\end{array}$ & $12 \mathrm{mo}$ & $12.4 \%$ of $\mathrm{BMI}$ & IL-18 $\downarrow 41 \%$ \\
\hline Dandona et al ${ }^{62} 1998$ & $\begin{array}{l}38 \text { obese women } \\
\text { BMI } 35.7 \pm 0.9\end{array}$ & $\begin{array}{l}925-1150 \mathrm{kcal} / \mathrm{d} \\
\text { energy-restricted diet and } \\
\text { increased aerobic exercise }\end{array}$ & $1-2 \mathrm{yr}$ & $12.3 \%$ of weight & TNF- $\alpha \downarrow 24 \%$ \\
\hline \multicolumn{6}{|l|}{$\begin{array}{l}\text { Medication use or } \\
\text { weight-loss surgery }\end{array}$} \\
\hline Vendrell et al ${ }^{57} 2004$ & $\begin{array}{l}34 \text { morbidly obese } \\
\text { BMI } 49.6 \pm 1.0\end{array}$ & Gastric bypass & $6 \mathrm{mo}$ & $\begin{array}{l}30 \% \text { of weight, } \\
62 \% \text { of fat mass }\end{array}$ & $\begin{array}{l}\text { IL- } 6 \downarrow 59 \% ; \text { sTNFR1 } \downarrow 15 \% \text {; } \\
\text { no change in sTNFR2 }\end{array}$ \\
\hline Valsamakis et al ${ }^{99} 2004$ & $\begin{array}{l}21 \text { obese women } \\
\text { BMI } 46.0 \pm 1.9\end{array}$ & 10-15 mg/d sibutramine & $6 \mathrm{mo}$ & $5.4 \%$ of weight & $\mathrm{CRP} \downarrow 10 \%$ \\
\hline Laimer et al ${ }^{65} 2002$ & $\begin{array}{l}20 \text { obese women } \\
\text { BMI } 41.6 \pm 1.2\end{array}$ & Adjustable gastric banding & $1 \mathrm{yr}$ & $\begin{array}{l}27 \% \text { of weight, } \\
45 \% \text { of fat mass }\end{array}$ & $\begin{array}{l}\text { CRP } \downarrow 70 \% \text {; } \\
\text { no change in IL-6 }\end{array}$ \\
\hline \multicolumn{6}{|c|}{$\begin{array}{l}\text { Randomized, controlled trials: } \\
\text { intervention group (versus control group) }\end{array}$} \\
\hline Esposito et al $^{56} 2003$ & $\begin{array}{l}120 \text { obese women } \\
\text { BMI } 35.0 \pm 2.3 \\
\text { (v. BMI } 34.7 \pm 2.4)\end{array}$ & $\begin{array}{l}1300-1500 \mathrm{kcal} / \mathrm{d} \text { energy- } \\
\text { restricted Mediterranean-style } \\
\text { American Heart Association } \\
\text { Step I diet (v. normal diet) }\end{array}$ & $2 \mathrm{yr}$ & $\begin{array}{l}14.7 \% \text { of weight } \\
\text { (v. } 3.2 \% \text { of weight) }\end{array}$ & $\begin{array}{l}\text { CRP } \downarrow 34 \% \text {; IL- } 6 \downarrow 33 \% \\
\text { (v. no changes in CRP, IL-6) }\end{array}$ \\
\hline Nicklas et al ${ }^{97} 2004$ & $\begin{array}{l}316 \text { older adults } \\
\text { BMI } 34.5 \pm 5.4 \\
(\text { v. BMI } 34.2 \pm 5.0)\end{array}$ & $\begin{array}{l}\text { Behavioural counselling } \\
\text { to achieve and keep a } 5 \% \\
\text { weight loss (v. normal diet) }\end{array}$ & $18 \mathrm{mo}$ & $\begin{array}{l}5.1 \% \text { of weight } \\
\text { (v. } 1.8 \% \text { of weight) }\end{array}$ & $\begin{array}{l}\text { CRP } \downarrow 3 \% ; \text { IL- } 6 \downarrow 11 \% ; \\
\text { sTNFR } 1 \downarrow 2 \% ; \text { no change } \\
\text { in TNF- } \alpha \text { (v. no changes) }\end{array}$ \\
\hline
\end{tabular}

Note: $\downarrow=$ decreased, $\mathrm{BMI}=$ mean body mass index \pm standard error of the mean, CRP $=$ C-reactive protein, IL $=$ interleukin, TNF $=$ tumour necrosis factor, $\mathrm{sTNFR}=$ soluble TNF- $\alpha$ receptor. 
lated in subcutaneous adipose tissue after 28 days on a verylow-energy diet that resulted in a 6-kg loss of fat mass. ${ }^{73}$ In another study involving obese women, ${ }^{53} 3$ weeks on a verylow-energy diet (3.9 GJ/d, 5\% drop in BMI) reduced IL-6 protein content in subcutaneous abdominal adipose tissue by $22 \%$, with a corresponding $15 \%$ decrease in circulating levels. Interestingly, moderate dietary restriction (a deficit of $2.5 \mathrm{GJ} / \mathrm{d}$ for 10 weeks, for a $7.5 \%$ weight loss) reduced IL-6 mRNA in abdominal adipose tissue by $35 \%$ and its secretion rate by $30 \%$, but decreased circulating IL-6 levels by only $6 \% .{ }^{100}$ Moreover, weight loss through caloric restriction reduced TNF- $\alpha$ gene e $^{87,101,102}$ and protein expression ${ }^{87}$ in, and TNF- $\alpha$ release from, abdominal adipose tissue..$^{102}$

The effects of weight loss on adipose-tissue expression or secretion of $\mathrm{CRP}^{81}$ are still unreported. More studies are needed to determine whether reductions in adipose-tissue production of inflammatory biomarkers is one mechanism by which weight loss reduces overall chronic inflammation.

\section{Role of physical activity and fitness in regulation of inflammation}

\section{Evidence from observational studies}

Although acute bouts of exercise are well known to increase concentrations of pro-inflammatory cytokines and acute-phase reactants, ${ }^{103}$ chronic (regular, long-term) physical training may reduce basal concentrations of inflammatory markers. Table 2 summarizes the data from crosssectional observational studies, which show an inverse association between markers of systemic inflammation and physical activity and fitness status..$^{50,104-112}$ Several studies of large population cohorts, including the British Regional Heart Study, ${ }^{106}$ the Third National Health and Nutrition Examination Survey, ${ }^{108,111}$ the Cardiovascular Health Study, ${ }^{105}$ the men's Health Professionals Follow-up Study, ${ }^{109}$ the Nurses' Health Study $\mathrm{II}^{109}$ and the Health, Aging and Body Composition Study (Health ABC), ${ }^{50}$ provide evidence for an inverse, independent dose-response relation between plasma CRP concentration and level of physical activity in both men and women.

This relation does not seem to alter with age: Of the 5888 participants in the Cardiovascular Health Study, ${ }^{105}$ those older and younger than 72 years showed similar associations; and among people 70-79 years old enrolled in Health ABC, ${ }^{50}$ trends for decreased IL-6, TNF- $\alpha$ and CRP concentrations were linear with increasing amounts of reported exercise. In the British Regional Heart Study, ${ }^{106}$ even moderate physical activity (i.e., some vigorous activity at least once per week) in middle-aged men was associated with a $37 \%$ reduction in the number who had a high CRP concentration $(>4.27 \mathrm{mg} / \mathrm{L})$. The relation was similar in men with and without prior heart disease. ${ }^{106} \mathrm{~A}$ dose-

Table 2: Summary of published data on associations between systemic markers of inflammation and physical activity or fitness

\begin{tabular}{|c|c|c|c|c|}
\hline $\begin{array}{l}\text { Author group and year } \\
\text { of publication (study name) }\end{array}$ & $\begin{array}{l}\text { No. of participants } \\
\text { (sex ratio) }\end{array}$ & $\begin{array}{l}\text { Age, } \\
\mathrm{yr}\end{array}$ & $\begin{array}{l}\text { Association between physical activity } \\
\text { and inflammatory markers }\end{array}$ & $\begin{array}{l}\text { Independent } \\
\text { of obesity? }\end{array}$ \\
\hline $\begin{array}{l}\text { Colbert et } \mathrm{al}^{50} 2004 \\
\text { (Health, Aging and Body Composition Study) }\end{array}$ & $3075(49 \%$ male $)$ & $70-79$ & $\begin{array}{l}\uparrow \mathrm{min} / \text { wk exercise } \Rightarrow \downarrow \text { CRP, IL- } 6 \text {, TNF- } \alpha \\
\uparrow \text { non-exercise PA } \Rightarrow \downarrow \text { CRP, IL- } 6\end{array}$ & $\begin{array}{l}\text { Yes, for } \\
\text { IL- } 6 \text { only }\end{array}$ \\
\hline $\begin{array}{l}\text { Albert et al }{ }^{112} 2004 \\
\text { (Pravastatin Inflammation/CRP Evaluation [PRINCE]) }\end{array}$ & $2833(61 \%$ male $)$ & $60 \pm 12$ & $\begin{array}{l}\uparrow \text { frequency of } \mathrm{PA} \Rightarrow \downarrow \mathrm{CRP} \text { in men only; } \\
\text { no PA-CRP relationship in women }\end{array}$ & Yes \\
\hline Jankord et al ${ }^{114} 2004$ & 12 men & $60-74$ & Very active $\Rightarrow \downarrow$ IL-6; less active $\Rightarrow \uparrow$ IL-10 & Not assessed \\
\hline Pischon et al ${ }^{109} 2003$ (HPFS and NHS II) & $\begin{array}{l}\text { HPFS: } 405 \text { men } \\
\text { NHS: } 454 \text { women }\end{array}$ & $\begin{array}{l}40-75 \\
25-42\end{array}$ & $\begin{array}{l}\uparrow \text { metabolic equivalent-hours/wk } \\
\Rightarrow \downarrow \text { CRP, IL-6, sTNFR1, sTNFR2 }\end{array}$ & No \\
\hline $\begin{array}{l}\text { Reuben et al }{ }^{110} 2003 \\
\text { (MacArthur Studies of Successful Aging) }\end{array}$ & 870 (47\% male) & $70-79$ & $\begin{array}{l}\uparrow \text { recreational activity } \Rightarrow \downarrow \text { CRP, IL- } 6 \\
\uparrow \text { house or yard work } \Rightarrow \downarrow C R P, \text { IL- } 6\end{array}$ & Yes \\
\hline King et al ${ }^{111} 2003$ (NHANES III) & $4072(50 \%$ male $)$ & $>17$ & $\begin{array}{l}\text { Jogging or aerobic dancing }>12 \text { times } / \mathrm{mo} \\
\text { protective for } \mathrm{CRP}>3 \mathrm{mg} / \mathrm{L}\end{array}$ & Yes \\
\hline Rawson et al ${ }^{113} 2003$ & 109 (57\% male) & $49 \pm 12$ & $\begin{array}{l}\text { CRP not related to current physical activity } \\
\text { or to physical activity during previous year }\end{array}$ & No \\
\hline $\begin{array}{l}\text { Wannamethee et al }{ }^{106} 2002 \\
\text { (British Regional Heart Study) }\end{array}$ & 3810 men & $60-79$ & $\begin{array}{l}\uparrow \text { volume of } \mathrm{PA} \Rightarrow \downarrow \mathrm{CRP} \text { (no PA } \\
\Rightarrow 2.29 \mathrm{mg} / \mathrm{L} ; \text { vigorous } \mathrm{PA} \Rightarrow 1.54 \mathrm{mg} / \mathrm{L})\end{array}$ & Yes \\
\hline $\begin{array}{l}\text { Church et al }{ }^{107} 2002 \\
\text { (Aerobics Center Longitudinal Study) }\end{array}$ & 722 men & $51 \pm 10$ & $\uparrow$ cardiorespiratory fitness $\Rightarrow \downarrow$ CRP & Yes \\
\hline Abramson et al ${ }^{108} 2002$ (NHANES III) & 3638 (51\% male) & $>40$ & More frequent exercise $\Rightarrow \downarrow$ CRP & Yes \\
\hline $\begin{array}{l}\text { Geffken et al }{ }^{105} 2001 \\
\text { (Cardiovascular Health Study) }\end{array}$ & $5888(42 \%$ male $)$ & $\geq 65$ & $\uparrow \mathrm{kcal} / \mathrm{wk}$ of physical activity $\Rightarrow \downarrow \mathrm{CRP}$ & Yes \\
\hline $\begin{array}{l}\text { Taaffe et al }{ }^{104} 2000 \\
\text { (MacArthur Studies of Successful Aging) }\end{array}$ & 880 (47\% male) & $70-79$ & $\uparrow \mathrm{h} / \mathrm{yr}$ moderate-strenuous PA $\Rightarrow \downarrow \mathrm{CRP}, \mathrm{IL}-6$ & Yes \\
\hline
\end{tabular}

Note: $\uparrow=$ increased, $\Rightarrow=$ led to, HPFS = Health Professionals' Follow-up Study, NHANES III = Third National Health and Nutrition Examination Survey, NHS II = Nurses' Health Study II, PA = physical activity; other symbols and abbreviations as defined in Table 1. 
longer-term behavioural changes involving reduced energy intake and increased physical activity, ${ }^{42,43,54,58,62,92-94}$ approved medication use ${ }^{95}$ or surgical gastric bypass. ${ }^{57,64} \mathrm{Re}-$ sults for liposuction are contradictory: Although one such study ${ }^{99}$ resulting in a mean weight loss of $3 \mathrm{~kg}$ found concentrations of IL-6, IL-18, TNF- $\alpha$ and CRP to be reduced after a 6-month period of weight stability, another ${ }^{96}$ in which fat mass was reduced by $9.8 \mathrm{~kg}$ on average found IL- 6 , TNF- $\alpha$ and CRP concentrations to be unaltered 10-12 weeks after the surgery. The effects of weight loss through liposuction for reducing inflammation thus require further investigation.

Most of the dietary weight-loss studies showed the magnitude of decrease in inflammatory markers to be linearly related to the amount of weight lost. For example, when CRP concentrations were reduced from $3.1 \mathrm{mg} / \mathrm{L}$ (standard deviation [SD] $0.7 \mathrm{mg} / \mathrm{L}$ ) to 1.6 (SD 0.8) $\mathrm{mg} / \mathrm{L}$ in postmenopausal women who followed a 14-month individualized weight-loss program ${ }^{42}$ the reductions correlated with changes in body weight and fat mass. Decreases in CRP, IL-6, IL-18 and TNF- $\alpha$ in a group of premenopausal women after a $10 \%$ weight reduction correlated with changes in BMI but were more strongly related to changes in waist-hip ratio. ${ }^{43,58}$ Those women were healthy, without diabetes or metabolic syndrome, and their mean reduction in CRP (from 3.4 [SD 0.7] to 1.9 [SD 0.2$] \mathrm{mg} / \mathrm{L}$ ) mimicked the mean reported in healthy women by Tchernof and coauthors. ${ }^{42}$ In other studies, weight loss reduced CRP levels (from 5.0 [SD 0.5] to 4.3 [SD 0.5] mg/L) in women with metabolic syndrome, ${ }^{91}$ and IL-6 concentrations (2.75 [SD 1.51] to 2.3 [SD 0.91] pg/ $\mathrm{mL}$ ) in women with insulin resistance. ${ }^{93}$

To date, only 2 randomized controlled trials ${ }^{5,97}$ have examined the effects of dietary weight loss on inflammation. Esposito and coworkers ${ }^{56}$ compared obese women enrolled in a behavioural counselling program designed to achieve a $10 \%$ weight reduction through monthly individualized advice on eating a low-energy Mediterranean-style diet and increasing physical activity with obese women in a control group who received no dietary advice. The 2-year intervention decreased BMI more in the women in the intervention group than in the control group $\left(-5.2 \mathrm{v} .-1.0 \mathrm{~kg} / \mathrm{m}^{2}\right)$ and reduced serum concentrations of CRP, IL- 6 and IL-18 to a greater degree as well. In the intervention group, the average CRP value decreased from 3.2 to $2.1 \mathrm{mg} / \mathrm{L}$, and the changes in CRP, IL-6 and IL-18 were found to relate to changes in BMI. Because exercise was included in the behavioural weight-loss intervention tested in this study, ${ }^{56}$ it is not possible to separate out the effects of the diet alone in producing these changes.

In a retrospective analysis of stored serum samples from a randomized clinical trial, ${ }^{97}$ our earlier research team found that an 18-month diet-induced weight loss program resulted in significantly greater reductions in body weight $(-5.1 \% \mathrm{v}$. $-1.8 \%$ ) and CRP, IL-6 and sTNFR1 concentrations than no weight-loss intervention in a control group of older, obese men and women with knee osteoarthritis (Fig. 2). Changes in sTNFR1, but not CRP and IL-6, correlated with changes in body weight. Although some of the participants randomly assigned to the weight-loss intervention were also randomly assigned to an exercise intervention, no interaction was found between weight loss and exercise training. ${ }^{97}$

In that prior study, ${ }^{97}$ the decrease in CRP concentrations in people who underwent diet-induced weight loss was $1.54 \mathrm{mg} / \mathrm{L}$ on average, or $5.8 \%$. In other studies, CRP values decreased $26 \%$ with a $10 \%$ weight $\operatorname{loss}^{89}$ and fell $32 \%-$ $34 \%$ with a $15 \%-16 \%$ weight loss. ${ }^{42,56}$ These results suggest that there may be a dose-response effect between the degree of weight loss and its capacity to attenuate chronic inflammation. Unfortunately, no data are available on clinical manifestations of this decline in CRP concentrations, although a CRP reduction of about $15 \%$ after 1 year of statin use was shown to be associated with a lowered risk of coronary events. ${ }^{98}$ Longitudinal studies are needed to determine whether a reduced incidence of cardiovascular disease and diabetes is associated with the decline in CRP concentrations seen with weight loss.

\section{Mechanism of effect}

One of the postulated mechanisms by which weight loss reduces circulating markers of inflammation is through a decrease in adipose-tissue cytokine production (Fig. 3). A handful of studies have investigated the effects of dietary weight loss on cytokine gene and protein expression in subcutaneous adipose tissue; most data indicate that local production of IL6 and TNF- $\alpha$ is reduced upon weight loss. Recently, geneexpression profiling showed that pro-inflammatory genes were downregulated and anti-inflammatory genes upregu-

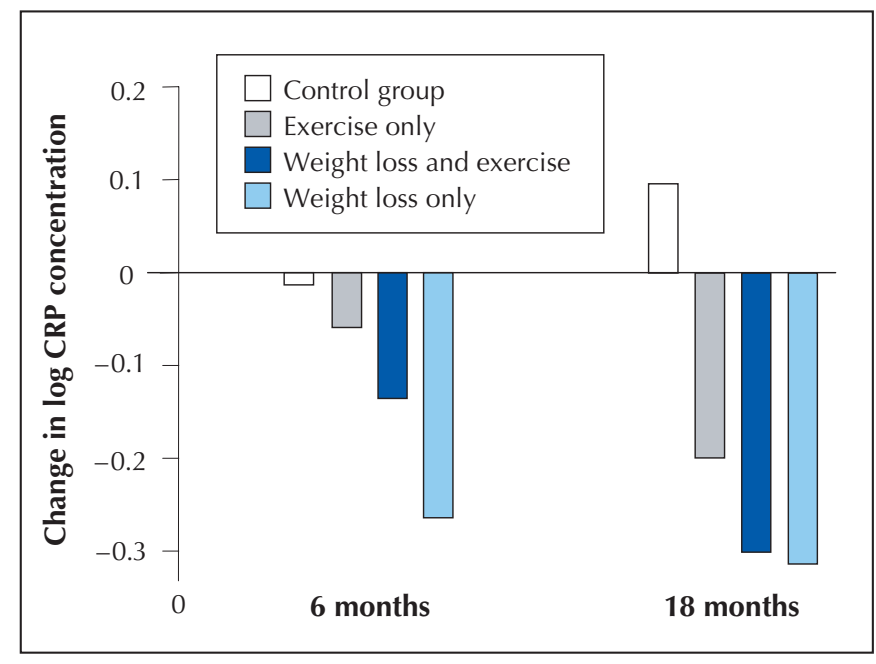

Fig. 2: Effects of 18 months of weight loss, exercise, or both upon mean CRP concentrations, adjusted for baseline BMI, baseline CRP level, sex and race. The treatment effect of dietary weight loss was significant compared with the control and exercise-only groups $(p=0.01)$. Modified from Nicklas et al (Am J Clin Nutr 2004;79:544-51), with permission. 
response relation between CRP level and exercise was also seen at baseline in men, but not women, enrolled in the Pravastatin Inflammation/CRP Evaluation Study, ${ }^{112}$ a finding that perhaps was confounded by the fact that the women were less likely than the men to be physically active.

In all of the studies described, the relations between inflammatory markers and physical activity were independent of differential levels of obesity. Contrary reports ${ }^{109,113}$ do exist, but their results may reflect chance findings owing to their small samples.
Although CRP is the marker of chronic inflammation most frequently studied, both IL-6 and CRP concentrations have been shown in elderly men to be inversely correlated to reported amounts of moderate and strenuous exercise, even after adjustment for BMI..$^{104,109}$ Similar studies have shown this to be true for recreational activity and house and yard work ${ }^{110,114}$ (although not consistently for IL- $6^{10}$ ).

All of the studies mentioned relied on self-report to assess physical activity status. In a subsample of 722 men from the Aerobics Center Longitudinal Study, Church and

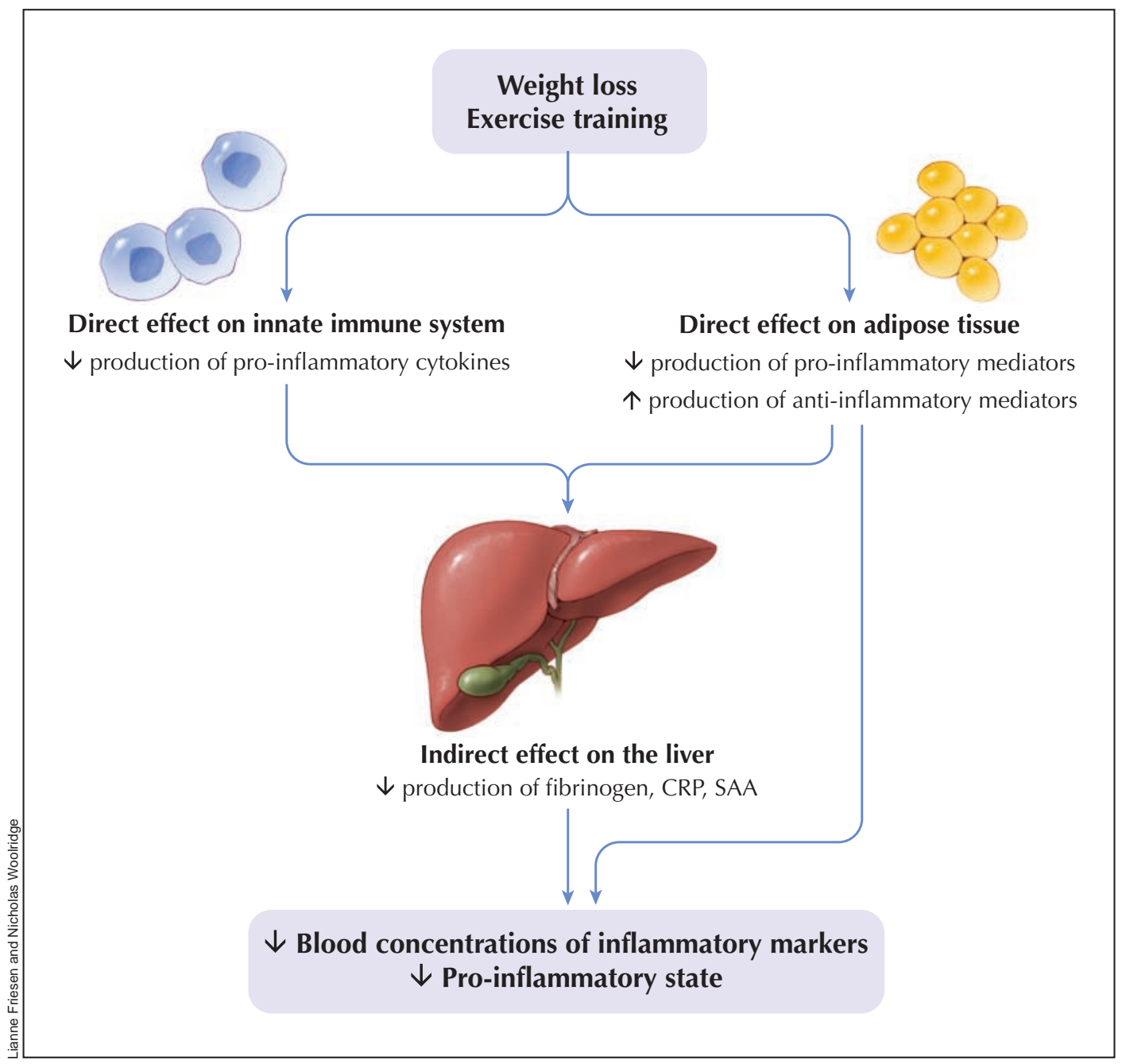

Fig. 3: Schematic of possible mechanisms by which weight loss and exercise training reduce sources of inflammation that lead to chronic activation of a pro-inflammatory state. Weight loss and increased activity affect the immune system by reducing the number of mononuclear cells in the peripheral blood, which are a source of pro-inflammatory cytokines (such as interleukins IL-6, IL-1 $\beta$ and IL8; tumour necrosis factor- $\alpha$ and its receptors TNFR1 and TNFR2; and transforming growth factor TGF $\beta$ ). A reduction in adipose tissue would not only reduce the volume of adipocytes and preadipocytes, but also decrease the number of endothelial cells and macrophages that reside there. These cells produce many pro-inflammatory mediators such as C-reactive protein (CRP), serum amyloid protein A (SAA) and cytokines. Weight loss and exercise may also increase the expression of antiinflammatory mediators such as IL-10 and IL-1 receptor antagonist (IL-1 ra) in these cells. The resulting circulatory changes could, in turn, cause the liver to contribute by decreasing its production of fibrinogen and other pro-inflammatory mediators. 
collaborators $^{107}$ reported that plasma CRP is also inversely related, in a dose-response manner, to cardiorespiratory fitness measured directly on a treadmill. The odds ratio of men in the lowest quintile of fitness for having a high CRP concentration $(>1.84 \mathrm{mg} / \mathrm{L})$ was 3.2 (95\% CI $1.8-5.8$ ), compared with men having higher fitness levels. Study investigators measured adiposity directly from the sum of skinfolds. Additional adjustments for body fat percentage and waist circumference did not alter the relation between CRP and cardiorespiratory fitness. ${ }^{107}$

Overall, data from observational studies show that the greater the volume of physical activity, the lower the risk of elevated levels of chronic inflammatory markers. Primarily, the relation between inflammation and physical activity is independent of obesity as measured by BMI. But since BMI is not a direct measure of body fat, the question remains, after adjustment for differences in total and abdominal adiposity, as to whether inflammation is associated with physical activity.

\section{Evidence from intervention studies}

Although no data from prospective randomized controlled trials exist to date to definitely conclude that longterm regular exercise training reduces chronic inflammation, several uncontrolled studies of exercise do show an effect on specific inflammatory markers. For instance, in patients with chronic heart failure, 12 weeks of aerobic exercise reduced TNF- $\alpha$ concentrations, ${ }^{115} 6$ weeks of cycle ergometry reduced sTNFR2 concentrations, ${ }^{116}$ and 16 weeks of combined aerobic and resistance exercise training decreased levels of both TNF receptors (but not TNF- $\alpha$ itself). ${ }^{17}$ In addition, exercise training for patients with intermittent claudication reduced CRP after 3 months. ${ }^{118}$ CRP decreased after 9 months of training for a marathon in 10 of 12 male runners. ${ }^{119}$ In overweight women, aerobic exercise training for 5 months decreased serum concentrations of TNF- $\alpha$, sTNFR1 and sTNFR2, ${ }^{120}$ and cycle ergometry for 12 weeks reduced TNF- $\alpha$ and sTNFR2 (but not sTNFR1) concentrations. ${ }^{121}$ Moreover, levels of acutephase reactants CRP and serum amyloid protein A (but not IL-6) decreased significantly in 20 postmenopausal women who completed a 14-day diet and aerobic exercise intervention as inpatients. ${ }^{122}$ The magnitude of the CRP decrease $(45 \%)$ in these women was not significantly related to the magnitude of weight loss (4\%). In another study, ${ }^{123}$ resistance exercise training decreased TNF- $\alpha$ (both mRNA and protein levels) in skeletal muscle of frail, elderly subjects, which suggests that resistance training is also a potential treatment for chronic inflammation.

All of these studies had a small number of participants, were conducted in populations with elevated inflammatory markers (i.e., patients with congestive heart failure or obesity) and had relatively short durations. One of the larger studies $^{124}$ to date, which incorporated a control group but did not randomly assign participants to groups, demon- strated that a phase II cardiac rehabilitation and exercise training program reduced median CRP concentrations by $41 \%$ (mean change from 5.9 [SD 7.7] $\mathrm{mg} / \mathrm{L}$ to 3.8 [SD 5.8] $\mathrm{mg} / \mathrm{L}$; median change from 3.4 to $2.0 \mathrm{mg} / \mathrm{L}$ ) in $235 \mathrm{pa}$ tients with coronary artery disease, but CRP concentrations did not change in 42 who did not exercise (Fig. 4). Exercise training seemed to be more effective in those with the highest CRP concentrations; for example, the proportion of patients with a CRP value above $15 \mathrm{mg} / \mathrm{L}$ decreased from $9 \%$ to $1 \%$. Stratification of the data according to use of statin therapy did not alter the results. Changes in CRP concentrations were unassociated with changes in body weight or percent body fat, which provided compelling evidence that the exercise training effect was independent of body fat loss. ${ }^{124}$ Another earlier research team of ours ${ }^{125}$ also found evidence for an independent effect of exercise training in postmenopausal women who underwent 6 months of dietary weight loss alone or in combination with aerobic exercise training. In this study, decreases in IL-6, sIL-6R and sTNFR1 differed significantly between the groups, with changes in sIL-6R and sTNFR1 concentrations inversely related to changes in aerobic fitness. ${ }^{125}$ Another interesting study ${ }^{126}$ was conducted specifically to determine the effects of a 6-month supervised, individualized aerobic exercise training program on the production of cytokines by mononuclear cells in men and women at high risk of ischemic heart disease. In the 43 people who completed the program, overall production of atherogenic cytokines (interferon $\gamma$, TNF- $\alpha$ and IL- $1 \alpha$ ) decreased by $58 \%$, and the production of atheroprotective cytokines (IL-10, IL-4 and transforming growth factor TGF 31 ) increased $36 \%$. (Their mean CRP level was 35\% lower after exercise training, but the difference was not statistically significant. ${ }^{126}$ )

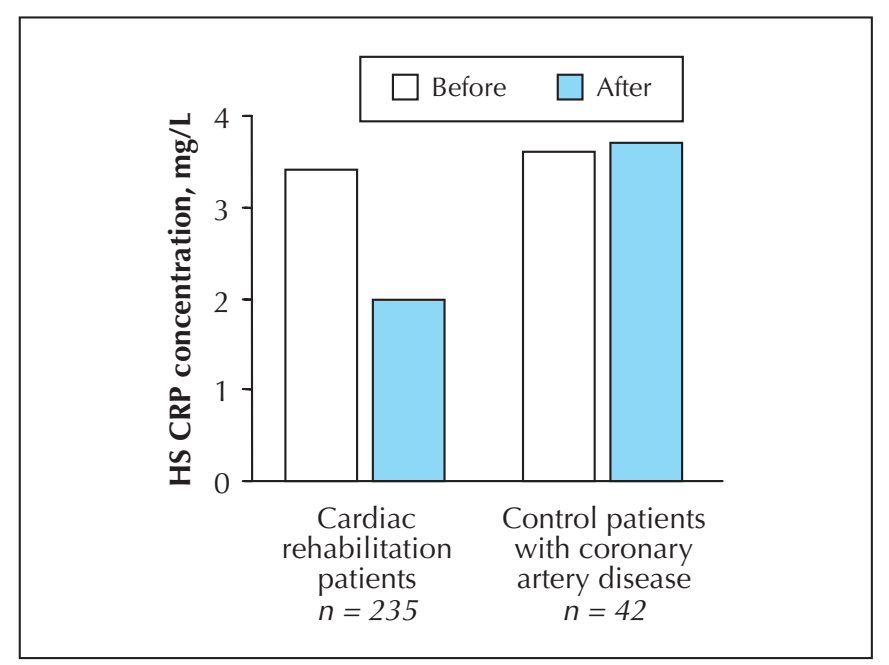

Fig. 4: Median changes in high-sensitivity (HS) C-reactive protein concentrations in patients with coronary heart disease after 19 weeks of follow-up (standard deviation 3 weeks) in cardiac rehabilitation compared with control patients with coronary artery disease. Reprinted with permission from Milani et al ( J Am Coll Cardiol 2004;43:1056-61). 
Only a few randomized controlled trials have been published that report the effects of an exercise intervention on inflammatory markers, and the data are conflicting. During a 6-year trial involving 140 middle-aged Finnish men, ${ }^{127}$ CRP concentrations remained consistantly lower in the aerobic exercise group than in the control group, but the trend was not statistically significant $(p>0.20)$. In the weight loss and exercise trial ${ }^{97}$ already described, our team also did not find an 18-month combined resistive and aerobic exercise training program to have a statistically significant effect on inflammatory biomarkers, although mean CRP values at follow-up visits tended to be lower in the intervention group than in the control group at both 6 and 18 months. Smaller studies $^{118,28}$ of shorter duration also hint that exercise training reduces inflammation compared with no exercise. In men with metabolic syndrome, 3 months of aerobic exercise decreased concentrations of monocyte chemoattractant protein- 1 by $33 \%$ and IL- 8 by $13 \% .{ }^{128}$ Although CRP levels in patients with intermittent claudication were significantly reduced after 3 months of a 12 -month exercise training program compared with levels in control subjects, ${ }^{118}$ CRP concentrations increased to baseline levels at the 6- and 12-month follow-up visits, perhaps because exercise in this study was unsupervised after the first 3 months. Interestingly, Gielen and associates ${ }^{129}$ reported that exercise training did not reduce serum inflammatory markers in male patients with congestive heart failure but did reduce TNF- $\alpha$, IL- 6 and IL- $1 \beta$ gene expression in local skeletal muscle, relative to a control group. This suggests that exercise may elicit local anti-inflammatory effects that may or may not be evident in the systemic circulation. ${ }^{129}$

Additional data derived from randomized controlled studies are needed to provide definitive evidence that exercise training should be used as a treatment for chronic inflammation.

\section{Summary}

Persistent low-grade inflammation is emerging as an important contributor to the pathophysiology of several chronic diseases. Given the widespread deleterious health effects of an augmented inflammatory state, identification of therapies that reduce inflammation is critical. Yet, to date, there is little definitive evidence for therapies that can be used effectively to treat elevated markers of inflammation that are within the clinically normal range. As reviewed here, there are promising data suggesting that decreasing energy intake and increasing physical activity could be effective for reducing overall inflammation. But at present, data from randomized controlled trials conducted to determine the effects of weight loss or exercise training, or both, on inflammation are lacking. The mechanisms by which weight loss and increased physical activity reduce inflammation have yet to be elucidated.
Although weight loss is likely to emerge as an effective treatment for reducing inflammation, the magnitude of the effect and the weight loss needed to produce clinically meaningful results require delineation. On the other hand, the effects of exercise training in the absence of weight loss are unclear. Large-scale prospective studies are needed to definitively determine whether aerobic or resistive exercise training, or both, are effective in reducing inflammation.

This article has been peer reviewed.

From the Sticht Center on Aging, Section on Gerontology and Geriatric Medicine, Department of Internal Medicine, Wake Forest University School of Medicine, Winston-Salem, NC (Nicklas, You); the Department of Aging and Geriatric Research and the University of Florida Institute on Aging, University of Florida, Gainesville, Fla. (Pahor)

Competing interests: None declared.

Contributors: All of the authors made substantial contributions to the writing of the paper, including comprehensive review of the literature, interpretation of findings and drafting of the text and figures.

Acknowledgements: This work was supported in part by the Wake Forest University Claude D. Pepper Older Americans Independence Center (National Institute on Aging [NIA] grant P30-AG-021332) and NIA grant R01-AG/DK-20583.

\section{References}

1. Kolb-Bachofen V. A review on the biological properties of C-reactive protein. Immunobiology 1991;183:133-45.

2. Gabay C, Kushner I. Acute-phase proteins and other systemic responses to inflammation. N Engl 7 Med 1999;340:448-54.

3. Ford ES, Giles WH, Myers GL, Mannino DM. Population distribution of high-sensitivity C-reactive protein among US men: findings from National Health and Nutrition Examination Survey 1999-2000. Clin Chem 2003;49: 686-90.

4. Ford ES, Giles WH, Mokdad AH, Myers GL. Distribution and correlates of C-reactive protein concentrations among adult US women. Clin Chem 2004; 50:574-81.

5. Pepys MB. C-reactive protein fifty years on. Lancet 1981;1:653-7.

6. Ballou SP, Kushner I. C-reactive protein and the acute phase response. Adv Intern Med 1992;37:313-36.

7. Morley JJ, Kushner I. Serum C-reactive protein levels in disease. Ann NY Acad Sci 1982;389:406-18.

8. Ridker PM, Cushman M, Stampfer MJ, Tracy RP, Hennekens CH. Inflammation, aspirin, and the risk of cardiovascular disease in apparently healthy men. NEngl 7 Med 1997;336:973-9.

9. Ridker PM, Rifai N, Pfeffer MA, Sacks FM, Moye LA, Goldman S, et al, for the Cholesterol and Recurrent Events (CARE) Investigators. Inflammation, pravastatin, and the risk of coronary events after myocardial infarction in patients with average cholesterol levels. Circulation 1998;98:839-44.

10. Rost NS, Wolf PA, Kase CS, Kelly-Hayes M, Silbershatz H, Massaro JM, et al. Plasma concentration of C-reactive protein and risk of ischemic stroke and transient ischemic attack: the Framingham study. Stroke 2001;32:2575-9.

11. Pradhan AD, Manson JE, Rossouw JE, Siscovick DS, Mouton CP, Rifai N, et al. Inflammatory biomarkers, hormone replacement therapy, and incident coronary heart disease: prospective analysis from the Women's Health Initiative observational study. FAMA 2002;288:980-7.

12. Pai JK, Pischon T, Ma J, Manson JE, Hankinson SE, Joshipura K, et al. Inflammatory markers and the risk of coronary heart disease in men and women. N Engl 7 Med 2004;351:2599-610.

13. Ridker PM. High-sensitivity C-reactive protein, inflammation, and cardiovascular risk: from concept to clinical practice to clinical benefit. Am Heart 7 2004;148:S19-26.

14. Tracy RP, Psaty BM, Macy E, Bovill EG, Cushman M, Cornell ES, et al. Lifetime smoking exposure affects the association of C-reactive protein with cardiovascular disease risk factors and subclinical disease in healthy elderly subjects. Arterioscler Thromb Vasc Biol 1997;17:2167-76.

15. Strandberg TE, Tilvis RS. C-reactive protein, cardiovascular risk factors, and mortality in a prospective study in the elderly. Arterioscler Thromb Vasc Biol 2000;20:1057-60.

16. Gussekloo J, Schaap MC, Frolich M, Blauw GJ, Westendorp RG. C-reactive protein is a strong but nonspecific risk factor of fatal stroke in elderly persons. Arterioscler Thromb Vasc Biol 2000;20:1047-51. 
17. Cesari M, Penninx BW, Newman AB, Kritchevsky SB, Nicklas BJ, SuttonTyrrell K, et al. Inflammatory markers and onset of cardiovascular events: results from the Health ABC study. Circulation 2003;108:2317-22.

18. Tice JA, Browner W, Tracy RP, Cummings SR. The relation of C-reactive protein levels to total and cardiovascular mortality in older U.S. women. Am $\mathcal{F}$ Med 2003:114:199-205.

19. Cao JJ, Thach C, Manolio TA, Psaty BM, Kuller LH, Chaves PH, et al. C-reactive protein, carotid intima-media thickness, and incidence of ischemic stroke in the elderly: the Cardiovascular Health Study. Circulation 2003;108:166-70.

20. Pearson TA, Mensah GA, Alexander RW, Anderson JL, Cannon RO 3rd, Criqui M, et al; Centers for Disease Control and Prevention; American Heart Association. Markers of inflammation and cardiovascular disease: application to clinical and public health practice: a statement for healthcare professionals from the Centers for Disease Control and Prevention and the American Heart Association. Circulation 2003;107:499-511.

21. Koukkunen H, Penttila K, Kemppainen A, Halinen M, Penttila I, Rantanen $\mathrm{T}$, et al. C-reactive protein, fibrinogen, interleukin-6 and tumour necrosis factor-alpha in the prognostic classification of unstable angina pectoris. Ann Med 2001;33:37-47.

22. Vasan RS, Sullivan LM, Roubenoff R, Dinarello CA, Harris T, Benjamin EJ, et al; Framingham Heart Study. Inflammatory markers and risk of heart failure in elderly subjects without prior myocardial infarction: the Framingham Heart Study. Circulation 2003;107:1486-91.

23. Duncan BB, Schmidt MI, Pankow JS, Ballantyne CM, Couper D, Vigo A, et al. Low-grade systemic inflammation and the development of type 2 diabetes: the atherosclerosis risk in communities study. Diabetes 2003;52:1799-805.

24. Pradhan AD, Manson JE, Rifai N, Buring JE, Ridker PM. C-reactive protein, interleukin 6, and risk of developing type 2 diabetes mellitus. $7 A M A 2001$; 286:327-34.

25. Penninx BW, Kritchevsky SB, Newman AB, Nicklas BJ, Simonsick EM, Rubin S, et al. Inflammatory markers and incident mobility limitation in the elderly. 7 Am Geriatr Soc 2004;52:1105-13.

26. Ferrucci L, Harris TB, Guralnik JM, Tracy RP, Corti MC, Cohen HJ, et al. Serum IL-6 level and the development of disability in older persons. $7 \mathrm{Am}$ Geriatr Soc 1999;47(6):639-46.

27. Streetz KL, Wustefeld T, Klein C, Manns MP, Trautwein C. Mediators of inflammation and acute phase response in the liver. Cell Mol Biol 2001;47:661-73.

28. Heinrich PC, Castell JV, Andus T. Interleukin-6 and the acute phase response. Biochem 7 1990;265:621-36.

29. Albert MA, Danielson E, Rifai N, Ridker PM, PRINCE investigators. Effect of statin therapy on C-reactive protein levels: the pravastatin inflammation/ CRP evaluation (PRINCE): a randomized trial and cohort study. $7 A M A$ 2001;286:64-70.

30. Pahor M, Franse LV, Deitcher SR, Cushman WC, Johnson KC, Shorr RI, et al. Fosinopril versus amlodipine comparative treatments study: a randomized trial to assess effects on plasminogen activator inhibitor-1. Circulation 2002; 105:457-61.

31. Kinlay S, Schwartz GG, Olsson AG, Rifai N, Leslie SJ, Sasiela WJ, et al; Myocardial Ischemia Reduction with Aggressive Cholesterol Lowering Study Investigators. High-dose atorvastatin enhances the decline in inflammatory markers in patients with acute coronary syndromes in the MIRACL study. Circulation 2003;108:1560-6.

32. Ridker PM, Cannon CP, Morrow D, Rifai N, Rose LM, McCabe CH, et al; Pravastatin or Atorvastatin Evaluation and Infection Therapy-Thrombolysis in Myocardial Infarction 22 (PROVE IT-TIMI 22) Investigators. C-reactive protein levels and outcomes after statin therapy. NEngl 7 Med 2005;352:20-8.

33. Visser M, Bouter LM, McQuillan GM, Wener MH, Harris TB. Elevated Creactive protein levels in overweight and obese adults. 7AMA 1999;282:2131-5.

34. Yudkin JS, Stehouwer CDA, Emeis JJ, Coppack SW. C-reactive protein in healthy subjects: associations with obesity, insulin resistance, and endothelial dysfunction. A potential role for cytokines originating from adipose tissue? Arterioscler Thromb Vasc Biol 1999;19:972-8.

35. Hak AE, Stehouwer CD, Bots ML, Polderman KH, Schalkwijk CG, Westendorp IC, et al. Associations of C-reactive protein with measures of obesity, insulin resistance, and subclinical atherosclerosis in healthy, middle-aged women. Arterioscler Thromb Vasc Biol 1999;19:1986-91.

36. Cook DG, Mendall MA, Whincup PH, Carey IM, Ballam L, Morris JE, et al. C-reactive protein concentration in children: relationship to adiposity and other cardiovascular risk factors. Atherosclerosis 2000;149:139-50.

37. Barinas-Mitchell E, Cushman M, Meilahn EN, Tracy RP, Kuller LH. Serum levels of C-reactive protein are associated with obesity, weight gain, and hormone replacement therapy in healthy postmenopausal women. Am 7 Epidemiol 2001;153:1094-101.

38. Lemieux I, Pascot A, Prud'homme D, Almeras N, Bogaty P, Nadeau A, et al. Elevated C-reactive protein: another component of the atherothrombotic profile of abdominal obesity. Arterioscler Thromb Vasc Biol 2001;21:961-7.

39. Festa A, D'Agostino R Jr, Williams K, Karter AJ, Mayer-Davis EJ, Tracy RP, et al. The relation of body fat mass and distribution to markers of chronic inflammation. Int 7 Obes Relat Metab Disord 2001;25:1407-15.

40. Visser M, Bouter LM, McQuillan GM, Wener MH, Harris TB. Low-grade systemic inflammation in overweight children. Pediatrics 2001;107:E13-8.
41. Weyer C, Yudkin JS, Stehouwer CD, Schalkwijk CG, Pratley RE, Tatarann PA. Humoral markers of inflammation and endothelial dysfunction in relation to adiposity and in vivo insulin action in Pima Indians. Atberosclerosis 2002;161:233-42.

42. Tchernof A, Nolan A, Sites CK, Ades PA, Poehlman ET. Weight loss reduces C-reactive protein levels in obese postmenopausal women. Circulation 2002;105:564-9.

43. Ziccardi P, Nappo F, Giugliano G, Esposito K, Marfella R, Cioffi M, et al. Reduction of inflammatory cytokine concentrations and improvement of endothelial functions in obese women after weight loss over one year. Circulation 2002;105(7):804-9

44. Sites CK, Toth MJ, Cushman M, L'Hommedieu GD, Tchernof A, Tracy $\mathrm{RP}$, et al. Menopause-related differences in inflammation markers and their relationship to body fat distribution and insulin-stimulated glucose disposal. Fertil Steril 2002;77:128-35.

45. Chu NF, Chang JB, Shieh SM. Plasma C-reactive protein concentrations in relation to 5 -year body weight change among children: the Taipei Children Heart Study. Int 7 Obes Relat Metab Disord 2003;27:735-9.

46. Tamakoshi K, Yatsuya H, Kondo T, Ishikawa M, Zhang H, Murata C, et al. Long-term body weight variability is associated with elevated C-reactive protein independent of current body mass index among Japanese men. Int 7 Obes Relat Metab Disord 2003;27:1059-65.

47. Pannacciulli N, Cantatore FP, Minenna A, Bellacicco M, Giorgino R, De Pergola G. C-reactive protein is independently associated with total body fat, central fat, and insulin resistance in adult women. Int 7 Obes Relat Metab Disord 2001;25:1416-20.

48. Guerrero-Romero F, Rodriguez-Moran M. Relation of C-reactive protein to features of the metabolic syndrome in normal glucose tolerant, impaired glucose tolerant, and newly diagnosed type 2 diabetic subjects. Diabetes Metab 2003;29:65-71.

49. Aronson D, Bartha P, Zinder O, Kerner A, Markiewicz W, Avizohar O, et al. Obesity is the major determinant of elevated C-reactive protein in subjects with the metabolic syndrome. Int 7 Obes Relat Metab Disord 2004;28:674-9.

50. Colbert LH, Visser M, Simonsick EM, Tracy RP, Newman AB, Kritchevsky $\mathrm{SB}$, et al. Physical activity, exercise, and inflammatory markers in older adults: findings from the Health, Aging and Body Composition Study. 7 Am Geriatr Soc 2004;52:1098-104.

51. Greenfield JR, Samaras K, Jenkins AB, Kelly PJ, Spector TD, Gallimore JR, et al. Obesity is an important determinant of baseline serum C-reactive protein concentration in monozygotic twins, independent of genetic influences. Circulation 2004;109:3022-8.

52. Kip KE, Marroquin OC, Kelley DE, Johnson BD, Kelsey SF, Shaw LJ, et al Clinical importance of obesity versus the metabolic syndrome in cardiovascular risk in women: a report from the Women's Ischemia Syndrome Evaluation (WISE) study. Circulation 2004;109:706-13.

53. Bastard JP, Jardel C, Bruckert E, Blondy P, Capeau J, Laville M, et al. Elevated levels of interleukin 6 are reduced in serum and subcutaneous adipose tissue of obese women after weight loss. 7 Clin Endocrinol Metab 2000;85:3338-42.

54. Roytblat L, Rachinsky M, Fisher A, Greemberg L, Shapira Y, Douvdevani A, et al. Raised interleukin-6 levels in obese patients. Obes Res 2000;8:673-5.

55. Vozarova B, Weyer C, Hanson K, Tataranni PA, Bogardus C, Pratley RE. Circulating interleukin-6 in relation to adiposity, insulin action, and insulin secretion. Obes Res 2001;9:414-7.

56. Esposito K, Pontillo A, Di Palo C, Giugliano G, Masella M, Marfella R, et al. Effect of weight loss and lifestyle changes on vascular inflammatory markers in obese women: a randomized trial. 7AMA 2003;289:1799-804.

57. Vendrell J, Broch M, Vilarrasa N, Molina A, Gomez JM, Gutierrez C, et al Resistin, adiponectin, ghrelin, leptin, and proinflammatory cytokines: relationships in obesity. Obes Res 2004;12:962-71.

58. Marfella R, Esposito K, Siniscalchi M, Cacciapuoti F, Giugliano F, Labriola $\mathrm{D}$, et al. Effect of weight loss on cardiac synchronization and proinflammatory cytokines in premenopausal obese women. Diabetes Care 2004;27:47-52.

59. Giugliano F, Esposito K, Di Palo C, Ciotola M, Giugliano G, Marfella R, et al. Erectile dysfunction associates with endothelial dysfunction and raised proinflammatory cytokine levels in obese men. F Endocrinol Invest 2004;27:665-9.

60. Ryan AS, Nicklas BJ. Reductions in plasma cytokine levels with weight loss improve insulin sensitivity in overweight and obese postmenopausal women. Diabetes Care 2004;27:1699-705

61. Mendall MA, Patel P, Asante M, Ballam L, Morris J, Strachan DP, et al. Relation of serum cytokine concentrations to cardiovascular risk factors and coronary heart disease. Heart 1997;78:273-7.

62. Dandona P, Weinstock R, Thusu K, Abdel-Rahman E, Aljada A, Wadden T. Tumor necrosis factor-alpha in sera of obese patients: fall with weight loss. $\mathcal{F}$ Clin Endocrinol Metab 1998;83:2907-10.

63. Ronnemaa T, Pulkki K, Kaprio J. Serum soluble tumor necrosis factor-alpha receptor 2 is elevated in obesity but is not related to insulin sensitivity: a study in identical twins discordant for obesity. 7 Clin Endocrinol Metab 2000;85:2728-32.

64. Bertin E, Nguyen P, Guenounou M, Durlach V, Potron G, Leutenegger M. Plasma levels of tumor necrosis factor-alpha (TNF- $\alpha$ ) are essentially dependent on visceral fat amount in type 2 diabetic patients. Diabetes Metab 2000; 26:178-82. 
65. Laimer M, Ebenbichler CF, Kaser S, Sandhofer A, Weiss H, Nehoda H, et al. Markers of chronic inflammation and obesity: a prospective study on the reversibility of this association in middle-aged women undergoing weight loss by surgical intervention. Int 7 Obes Relat Metab Disord 2002;26:659-62.

66. Hotamisligil GS, Arner P, Atkinson RL, Spiegelman BM. Differential regulation of the p80 tumor necrosis factor receptor in human obesity and insulin resistance. Diabetes 1997;46:451-5.

67. Hauner H, Bender M, Haastert B, Hube F. Plasma concentrations of soluble TNF-alpha receptors in obese subjects. Int 7 Obes Relat Metab Disord 1998;22: 1239-43.

68. Bullo M, Garcia-Lorda P, Peinado-Onsurbe J, Hernandez M, Del Castillo D, Argiles JM, et al. TNFalpha expression of subcutaneous adipose tissue in obese and morbid obese females: relationship to adipocyte LPL activity and leptin synthesis. Int 7 Obes Relat Metab Disord 2002;26:652-8.

69. Straczkowski M, Dzienis-Straczkowska S, Stepien A, Kowalska I, Szelachowska M, Kinalska I. Plasma interleukin-8 concentrations are increased in obese subjects and related to fat mass and tumor necrosis factor-alpha system. 7 Clin Endocrinol Metab 2002;87:4602-6.

70. Bruun JM, Verdich C, Toubro S, Astrup A, Richelsen B. Association between measures of insulin sensitivity and circulating levels of interleukin-8, interleukin-6 and tumor necrosis factor-alpha. Effect of weight loss in obese men. Eur 7 Endocrinol 2003;148:535-42.

71. Olusi SO, Al Awadhi A, Abraham M. Relations of serum interleukin 18 levels to serum lipid and glucose concentrations in an apparently healthy adult population. Horm Res 2003;60:29-33.

72. Meier CA, Bobbioni E, Gabay C, Assimacopoulos-Jeannet F, Golay A, Dayer JM. IL-1 receptor antagonist serum levels are increased in human obesity: possible link to the resistance to leptin? 7 Clin Endocrinol Metab 2002;87:1184-8.

73. Clement K, Viguerie N, Poitou C, Carette C, Pelloux V, Curat CA, et al. Weight loss regulates inflammation-related genes in white adipose tissue of obese subjects. FASEB 7 2004;18:1657-69.

74. Chiellini C, Santini F, Marsili A, Berti P, Bertacca A, Pelosini C, et al. Serum haptoglobin: a novel marker of adiposity in humans. 7 Clin Endocrinol Metab 2004:89:2678-83.

75. Lin Y, Rajala MW, Berger JP, Moller DE, Barzilai N, Scherer PE. Hyperglycemia-induced production of acute phase reactants in adipose tissue. 7 Biol Chem 2001;276:42077-83.

76. Yang $\mathrm{R}$, Lee $\mathrm{M}, \mathrm{Hu} \mathrm{H}$ et al. Acute-phase protein serum amyloid protein A (SAA) is a pro-inflammatory adipocytokine in humans [abstract]. Diabetes 2004;53:A12

77. Forouhi NG, Sattar N, McKeigue PM. Relation of C-reactive protein to body fat distribution and features of the metabolic syndrome in Europeans and South Asians. Int 7 Obes Relat Metab Disord 2001;25:1327-31.

78. Saijo Y, Kiyota N, Kawasaki Y, Miyazaki Y, Kashimura J, Fukuda M, et al. Relationship between C-reactive protein and visceral adipose tissue in healthy Japanese subjects. Diabetes Obes Metab 2004;6:249-58.

79. Kershaw EE, Flier JS. Adipose tissue as an endocrine organ. 7 Clin Endocrinol Metab 2004;89:2548-56

80. Trayhurn P, Wood IS. Adipokines: inflammation and the pleiotropic role of white adipose tissue. Br 7 Nutr 2004;92:347-55.

81. Ouchi N, Kihara S, Funahashi T, Nakamura T, Nishida M, Kumada M, et al. Reciprocal association of C-reactive protein with adiponectin in blood stream and adipose tissue. Circulation 2003;107:671-4

82. Fain JN, Madan AK, Hiler ML, Cheema P, Bahouth SW. Comparison of the release of adipokines by adipose tissue, adipose tissue matrix, and adipocytes from visceral and subcutaneous abdominal adipose tissues of obese humans. Endocrinology 2004;145:2273-82.

83. Weisberg SP, McCann D, Desai M, Rosenbaum M, Leibel RL, Ferrante AW Jr. Obesity is associated with macrophage accumulation in adipose tissue. $\mathcal{F}$ Clin Invest 2003;112:1796-808.

84. Mohamed-Ali V, Goodrick S, Bulmer K, Holly JM, Yudkin JS, Coppack SW. Production of soluble tumor necrosis factor receptors by human subcutaneous adipose tissue in vivo. Am 7 Physiol 1999;277:E971-5.

85. Dusserre E, Moulin P, Vidal H. Differences in mRNA expression of the proteins secreted by the adipocytes in human subcutaneous and visceral adipose tissue. Bioch Biophys Acta 2000;1500:88-96.

86. Winkler G, Kiss S, Keszthelyi L, Sapi Z, Ory I, Salamon F, et al. Expression of tumor necrosis factor (TNF)-alpha protein in the subcutaneous and visceral adipose tissue in correlation with adipocyte cell volume, serum TNF-alpha, soluble serum TNF-receptor-2 concentrations and C-peptide level. Eur 7 Endocrinol 2003;149:129-35.

87. Kern P, Saghizadeh M, Ong J, Bosch R, Deem R, Simsolo R. The expression of tumor necrosis factor in human adipose tissue. Regulation by obesity, weight loss, and relationship to lipoprotein lipase. 7 Clin Invest 1995;95(5): 2111-9.

88. Bastard JP, Jardel C, Bruckert E, Vidal H, Hainque B. Variations in plasma soluble tumour necrosis factor receptors after diet-induced weight loss in obesity. Diabetes Obes Metab 2000;2:323-5.

89. Heilbronn LK, Noakes M, Clifton PM. Energy restriction and weight loss on very-low-fat diets reduce C-reactive protein concentrations in obese, healthy women. Arterioscler Thromb Vasc Biol 2001;21:968-70.
90. Gallistl S, Sudi KM, Aigner R, Borkenstein M. Changes in serum interleukin6 concentrations in obese children and adolescents during a weight reduction program. Int 7 Obes Relat Metab Disord 2001;25:1640-3.

91. Xydakis AM, Case CC, Jones PH, Hoogeveen RC, Liu MY, Smith EO, et al. Adiponectin, inflammation, and the expression of the metabolic syndrome in obese individuals: the impact of rapid weight loss through caloric restriction. 7 Clin Endocrinol Metab 2004;89:2697-703.

92. Esposito K, Pontillo A, Ciotola M, Di Palo C, Grella E, Nicoletti G, et al Weight loss reduces interleukin-18 levels in obese women. 7 Clin Endocrinol Metab 2002;87:3864-6.

93. Monzillo LU, Hamdy O, Horton ES, Ledbury S, Mullooly C, Jarema C, et al. Effect of lifestyle modification on adipokine levels in obese subjects with insulin resistance. Obes Res 2003;11:1048-54.

94. Seshadri P, Iqbal N, Stern L, Williams M, Chicano KL, Daily DA, et al. A randomized study comparing the effects of a low-carbohydrate diet and a conventional diet on lipoprotein subfractions and C-reactive protein levels in patients with severe obesity. Am 7 Med 2004;117:398-405.

95. Giugliano G, Nicoletti G, Grella E, Giugliano F, Esposito K, Scuderi N, et al. Effect of liposuction on insulin resistance and vascular inflammatory markers in obese women. Br 7 Plast Surg 2004;57:190-4.

96. Klein S, Fontana L, Young VL, Coggan AR, Kilo C, Patterson BW, et al. Absence of an effect of liposuction on insulin action and risk factors for coronary heart disease. $N$ Engl 7 Med 2004;350:2549-57.

97. Nicklas BJ, Ambrosius W, Messier SP, Miller GD, Penninx BW, Loeser RF, et al. Diet-induced weight loss, exercise, and chronic inflammation in older, obese adults: a randomized controlled clinical trial. Am 7 Clin Nutr 2004;79:544-51.

98. Ridker PM, Rifai N, Clearfield M, Downs JR, Weis SE, Miles JS, et al; Air Force/Texas Coronary Atherosclerosis Prevention Study Investigators. Measurement of C-reactive protein for the targeting of statin therapy in the primary prevention of acute coronary events. N Engl F Med 2001;344:1959-65.

99. Valsamakis G, McTernan PG, Chetty R, Al Daghri N, Field A, Hanif W, et al. Modest weight loss and reduction in waist circumference after medical treatment are associated with favorable changes in serum adipocytokines. $\mathrm{Me}$ tabolism 2004;53:430-4

100. Arvidsson E, Viguerie N, Andersson I, Verdich C, Langin D, Arner P. Effects of different hypocaloric diets on protein secretion from adipose tissue of obese women. Diabetes 2004;53:1966-71.

101. Hotamisligil GS, Arner P, Caro JF, Atkinson RL, Spiegelman BM. Increased adipose tissue expression of tumor necrosis factor-alpha in human obesity and insulin resistance. 7 Clin Invest 1995;95:2409-15.

102. Bruun JM, Pedersen SB, Kristensen K, Richelsen B. Opposite regulation of interleukin- 8 and tumor necrosis factor-alpha by weight loss. Obes Res 2002 ; 10:499-506.

103. Moldoveanu AI, Shephard RJ, Shek PN. The cytokine response to physical activity and training. Sports Med 2001;31:115-44.

104. Taaffe, DR, Harris TB, Ferrucci L, Rowe J, Seeman TE. Cross-sectional and prospective relationships of Interleukin-6 and C-reactive protein with physical performance in elderly persons: MacArthur studies of successful aging. $\mathcal{F}$ Gerontol 2000;55A(12):M709-15.

105. Geffken D, Cushman M, Burke G, Polak J, Sakkinen P, Tracy R. Association between physical activity and markers of inflammation in a healthy elderly population. Am 7 Epidemiol 2001;153:242-50.

106. Wannamethee SG, Lowe GD, Whincup PH, Rumley A, Walker M, Lennon L. Physical activity and hemostatic and inflammatory variables in elderly men. Circulation 2002;105:1785-90.

107. Church TS, Barlow CE, Earnest CP, Kampert JB, Priest EL, Blair SN. Associations between cardiorespiratory fitness and C-reactive protein in men. $\mathrm{Ar}$ terioscler Thromb Vasc Biol 2002;22:1869-76.

108. Abramson JL, Vaccarino V. Relationship between physical activity and inflammation among apparently healthy middle-aged and older US adults. Arch Intern Med 2002;162:1286-92.

109. Pischon T, Hankinson SE, Hotamisligil GS, Rifai N, Rimm EB. Leisure-time physical activity and reduced plasma levels of obesity-related inflammatory markers. Obes Res 2003;11:1055-64.

110. Reuben DB, Judd-Hamilton L, Harris TB, Seeman TE. The associations between physical activity and inflammatory markers in high-functioning older persons: MacArthur Studies of Successful Aging. 7 Am Geriatr Soc 2003;51:1125-30.

111. King DE, Carek P, Mainous AG III, Pearson WS. Inflammatory markers and exercise: differences related to exercise type. Med Sci Sports Exerc 2003;35 575-81.

112. Albert MA, Glynn RJ, Ridker PM. Effect of physical activity on serum Creactive protein. Am 7 Cardiol 2004;93:221-5.

113. Rawson ES, Freedson PS, Osganian SK, Matthews CE, Reed G, Ockene IS Body mass index, but not physical activity, is associated with C-reactive protein. Med Sci Sports Exerc 2003;35:1160-6.

114. Jankord R, Jemiolo B. Influence of physical activity on serum IL-6 and IL-10 levels in healthy older men. Med Sci Sports Exerc 2004:36:960-4.

115. Larsen AI, Aukrust P, Aarsland T, Dickstein K. Effect of aerobic exercise training on plasma levels of tumor necrosis factor alpha in patients with heart failure. Am 7 Cardiol 2001;88:805-8.

116. LeMaitre JP, Harris S, Fox KA, Denvir M. Change in circulating cytokines 
after 2 forms of exercise training in chronic stable heart failure. Am Heart 7 2004;147:100-5.

117. Conraads VM, Beckers P, Bosmans J, De Clerck LS, Stevens WJ, Vrints CJ, et al. Combined endurance/resistance training reduces plasma TNF-alpha receptor levels in patients with chronic heart failure and coronary artery disease. Eur Heart 7 2002;23:1854-60.

118. Tisi PV, Hulse M, Chulakadabba A, Gosling P, Shearman CP. Exercise training for intermittent claudication: does it adversely affect biochemical markers of the exercise-induced inflammatory response? Eur 7 Vasc Endovasc Surg 1997;14:344-50.

119. Mattusch F, Dufaux B, Heine O, Mertens I, Rost R. Reduction of the plasma concentration of C-reactive protein following nine months of endurance training. Int 7 Sports Med 2000;21:21-4.

120. Tsukui S, Kanda T, Nara M, Nishino M, Kondo T, Kobayashi I. Moderateintensity regular exercise decreases serum tumor necrosis factor-alpha and HbA1c levels in healthy women. Int 7 Obes Relat Metab Disord 2000;24:1207-11.

121. Straczkowski M, Kowalska I, Dzienis-Straczkowska S, Stepien A, Skibinska E, Szelachowska M, et al. Changes in tumor necrosis factor-alpha system and insulin sensitivity during an exercise training program in obese women with normal and impaired glucose tolerance. Eur 7 Endocrinol 2001;145:273-80.

122. Wegge JK, Roberts CK, Ngo TH, Barnard RJ. Effect of diet and exercise intervention on inflammatory and adhesion molecules in postmenopausal women on hormone replacement therapy and at risk for coronary artery disease. Metabolism 2004;53:377-81.

123. Greiwe JS, Cheng B, Rubin DC, Yarasheski KE, Semenkovich CF. Resistance exercise decreases skeletal muscle tumor necrosis factor alpha in frail elderly humans. FASEB 7 2001;15:475-82.
124. Milani RV, Lavie CJ, Mehra MR. Reduction in C-reactive protein through cardiac rehabilitation and exercise training. 7 Am Coll Cardiol 2004:43:1056-61.

125. You T, Berman DM, Ryan AS, Nicklas BJ. Effects of hypocaloric diet and exercise training on inflammation and adipocyte lipolysis in obese postmenopausal women. 7 Clin Endocrinol Metab 2004;89:1739-46.

126. Smith JK, Dykes R, Douglas JE, Krishnaswamy G, Berk S. Long-term exercise and atherogenic activity of blood mononuclear cells in persons at risk of developing ischemic heart disease. FAMA 1999;281:1722-7.

127. Rauramaa R, Halonen P, Vaisanen SB, Lakka TA, Schmidt-Trucksass A Berg A, et al. Effects of aerobic physical exercise on inflammation and atherosclerosis in men: the DNASCO Study: a six-year randomized, controlled trial Ann Intern Med 2004;140:1007-14.

128. Troseid M, Lappegard KT, Claudi T, Damas JK, Morkrid L, Brendberg R, et al. Exercise reduces plasma levels of the chemokines MCP-1 and IL-8 in subjects with the metabolic syndrome. Eur Heart 7 2004;25:349-55.

129. Gielen S, Adams V, Mobius-Winkler S, Linke A, Erbs S, Yu J, et al. Antiinflammatory effects of exercise training in the skeletal muscle of patients with chronic heart failure. 7 Am Coll Cardiol 2003;42:861-8.

Correspondence to: Barbara J. Nicklas, Section on Gerontology, Internal Medicine, Wake Forest University School of Medicine, Medical Center Blvd., Winston-Salem NC 27157, USA; fax336 713-8588; bnicklas@wfubmc.edu

\section{Clinical practice guidelines}

\section{FOR THE CARE AND TREATMENT OF \\ BREAST CANCER}

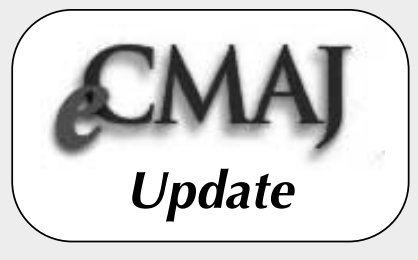

In February 1998 CMAJ and Health Canada published 10 clinical practice guidelines for the care and treatment of breast cancer, along with a lay version designed to help patients understand more about this disease and the recommended treatments. These guidelines are currently being revised and updated, and the series is being extended to cover new topics. The complete text of the new and updated guidelines is available at cmaj.ca:

\section{cmaj.ca/cgi/content/full/158/3/DC1}

REVISED:

Guideline 3: Mastectomy or lumpectomy? The choice of operation for clinical stages I and II breast cancer [July 23, 2002]

Guideline 5: The management of ductal carcinoma in situ [Oct. 2, 2001]

Guideline 6: Breast radiotherapy after breastconserving surgery [Feb. 18, 2003]

Guideline 7: Adjuvant systemic therapy for women with node-negative breast cancer [Jan. 23, 2001]

Guideline 8: Adjuvant systemic therapy for women with node-positive breast cancer [Mar. 6, 2001]

Guideline 10: The management of chronic pain in patients with breast cancer [Oct. 30, 2001]
NEW:

Guideline 11: Lymphedema [Jan. 23, 2001]

Guideline 12: Chemoprevention [June 12, 2001]

Guideline 13: Sentinel node biopsy [July 24, 2001]

Guideline 14: The role of hormone replacement therapy in women with a previous diagnosis of breast cancer [Apr. 16, 2002]

Guideline 15: Treatment for women with stage III or locally advanced breast cancer [Mar. 16, 2004]

Guideline 16: Locoregional post-mastectomy radiotherapy [Apr. 13, 2004] 